\title{
A 100\% renewable energy system in the year 2050: The case of Macedonia
}

\author{
Boris Ćosić $^{*, 1}$, Goran Krajačić ${ }^{2,3}$, Neven Duić ${ }^{2,3}$ \\ Faculty of Mechanical Engineering and Naval Architecture, University of Zagreb, Zagreb, Croatia
}

\section{A $\quad$ R $T$ T I C C L E I I N F O}

\section{Article history:}

Received 4 November 2011

Received in revised form

29 June 2012

Accepted 29 June 2012

Available online 1 August 2012

\section{Keywords:}

EnergyPLAN

$100 \%$ Renewable energy system

Energy system of Macedonia

Economic evaluation

\begin{abstract}
A B S T R A C T
The most important problems the energy sector faces in Macedonia are an unfavourable energy mix with a high prevalence of lignite, a strong dependence on energy import, poor condition of the energy system and inefficiency in energy production and use. This paper investigates the prospects for realization of the $100 \%$ renewable energy system in Macedonia by making use of the EnergyPLAN model. Analysis was conducted for two renewable scenarios designed for the years 2030 and 2050. First scenario, the 50\% renewable energy system, has been created for the year 2030 and represents the first step towards the $100 \%$ renewable energy future of Macedonia. The second scenario has been designed for the $100 \%$ renewable energy system based only on the renewable energy sources (RES) in the year 2050. Special attention in the design of these systems has been given to intermittent RES and to storage technologies. The analysis reveals that at the moment the 50\% renewable energy system seems much more likely than the $100 \%$ renewable energy system, but with additional energy efficiency measures, which will lead to a decrease of consumption and with installation of new generation capacities this goal can be easily achieved.
\end{abstract}

(c) 2012 Elsevier Ltd. All rights reserved.

\section{Introduction}

The rising dependency on energy imports, increase of greenhouse gas (GHG) emissions and high and unstable energy prices are some of the problems that Europe is facing today. One of the most promising ways for reducing Europe's dependency on energy imports and for diversification of energy resources, which at the same time reduces GHG emissions, are renewable energy sources (RES). Hence, the common goal of the European Union is to increase the share of RES in the final energy consumption to $20 \%$ in 2020 and to reduce GHG emissions by $20 \%$ until 2020 in comparison to their levels in 1990, and by 30\% until 2030 if the other developed countries undertake similar steps [1]. The main problem of RES, except biomass, geothermal and hydro, is their intermittent nature, so in order to use them effectively it is necessary to have energy storage in the system $[2,3]$. Because of the high investment costs in the storage systems the usage of RES is becoming even more expensive [4-6].

\footnotetext{
* Corresponding author. Tel.: +385 16168242; fax: +385 16156940 .

E-mail addresses: boris.cosic@fsb.hr (B. Ćosić), goran.krajacic@fsb.hr

(G. Krajačić), neven.duic@fsb.hr (N. Duić).

1 http://www.powerlab.fsb.hr/bcosic.

2 http://www.powerlab.fsb.hr/gkrajacic.

3 http://www.powerlab.fsb.hr/neven.
}

Analyses for the $100 \%$ renewable energy systems have been conducted in many studies and the conclusion is that the development of such systems with existing technology is possible and "it is not a matter of technology, but rather a matter of making the right choices today to shape tomorrow" [7]. Analyses of $100 \%$ renewable energy systems are already conducted for countries: Denmark [8], Croatia [9], Portugal [10], Ireland [11], New Zealand [12] and Australia [13]; towns: Aalborg [14] and Frederikshavn [15]; islands: Island of Mljet [2], Island of Sao Vicente [16] and Porto Santo Island [17]; and recently, incentives for $100 \%$ renewable energy future of the European Union [7]. In most analyses, biomass is used as the main resource for reaching $100 \%$ renewable energy systems $[8,11]$. Also, pumped hydro storage in the combination with wind, biomass and heat pumps has been proposed in many studies as the solution for the $100 \%$ renewable energy system $[9,12,14,18]$.

In the case of Macedonia, energy production is based mainly on the low-quality domestic lignite, biomass and hydro. According to EUROSTAT [19], in the year 2008 the share of lignite in total primary energy consumption was $51 \%$, followed by biomass with $6 \%$, hydro power with $2.3 \%$, and geothermal energy with the share of $0.3 \%$. Furthermore, in the energy balance for the year 2008, imported electricity participated with $7.6 \%$ [19] in total primary energy consumption and in the recent years import of electricity has had even rising trends due to increased electricity demand [20]. Also, the highest load demands occur in the winter season, mainly because of the electric heating used to supplement fuelwood heating in the 
residential sector during very cold periods [21]. In short, the most important problems that energy sector faces with are unfavourable energy mix with high prevalence of lignite, strong dependence on energy import, poor condition of the energy systems and high degree of inefficiency in energy production and use [22,23].

The current Macedonian energy strategy is not directed towards the $100 \%$ renewable energy system, but the usage of RES is maximised in all official scenarios. According to the Macedonian energy strategy [24], planned consumption of the biomass for the combustion in 2030 is around $3000 \mathrm{GWh}$, consumption of geothermal energy is expected to be $620-730 \mathrm{GWh}$, RES for the production of electricity are planned at $4600 \mathrm{GWh}$ and planned share of RES in the electricity generation in 2030 is $30 \%$.

This paper presents scenarios for the renewable energy future of Macedonia based only on the RES used for production of electricity, heat and biofuels. First scenario, the 50\% renewable energy system, has been created for the year 2030 and represents the first step towards the $100 \%$ renewable energy future of Macedonia. The second scenario has been designed for the $100 \%$ renewable energy system based only on the RES in the year 2050.

\section{Methodology}

In order to conduct analysis for the $100 \%$ renewable energy system of Macedonia, the EnergyPLAN model has been used [25]. The EnergyPLAN model is the input/output model used for the annual analyses of regional and national energy systems in steps of one hour. In order to complete calculations in a very short period of time and to have a very simple simulation process, the EnergyPLAN model uses analytic programming instead of iteration, and aggregated data inputs for the different units in various sectors.

The EnergyPLAN model is specialized in the large scale integration of the renewables in the energy system [26,27], optimal combinations of the renewables [28], implementation of the combined heat and power plants (CHP) in the energy systems [29], implementation of transportation in the energy sector $[30,31]$, simulation of the $100 \%$ renewable energy systems $[8,9,15]$ and for identification of the most appropriate market auction settings for electricity in the fossil free energy systems [32]. Typical input data are demands, RES, generation unit's capacities, storage capacities, fuel consumptions in individual, transport and industry sector, fuel costs, investment, variable and fixed operation and maintenance costs of different units, $\mathrm{CO}_{2}$ emissions factors of fuels and different regulation strategies. The output data are annual, monthly and hourly values of electricity production, electricity import/export, import expenditures and export revenues, fuel consumption, $\mathrm{CO}_{2}$ emissions and the share of RES. The model for analysis requires demand time series for electricity, district heating, individual heating, cooling and transport as well as distribution curve with an hourly resolution for wind, hydro, solar thermal, photo voltaic, geothermal and nuclear. Schematic diagram of the EnergyPLAN model is presented in Fig. 1.

Furthermore, the model can be used for technical analysis, market exchange analysis and feasibility studies. For these analyses technical regulation and electricity market strategies can be used. The technical regulation strategies try to minimise the import/ export of electricity and fuel consumption while in the market exchange analysis each plant optimises according to businesseseconomic profits, including any taxes and $\mathrm{CO}_{2}$ emission's costs. The model has four technical regulation strategies, and one electricity market strategy. The most commonly used strategies for the analysis are listed below:

1. Technical regulation strategy - balancing heat demands. CHPs produce only according to the heat demands

2. Technical regulation strategy - balancing both heat and electricity demand. CHP plants operate according to electricity and heat demand

3. Electricity market strategy. Plant optimisation based on business economic marginal production costs

Technical regulation strategy - balancing both heat and electricity demands, has been used in the analysis of Macedonian energy system. In this strategy, large heat pumps in combination with CHP units are used to minimise export of electricity. Decrease in electricity production from CHP units lead to decrease in heat production which is balanced by increase in the heat produced by the large heat pumps at the CHP plants. Also, during the summer period, when the heat demand is very low and electricity load high, large CHP plants in district heating group III are working as condensing plants. Furthermore, in the analyses of the Macedonian energy sector in Refs [34,35], EnergyPLAN model and technical

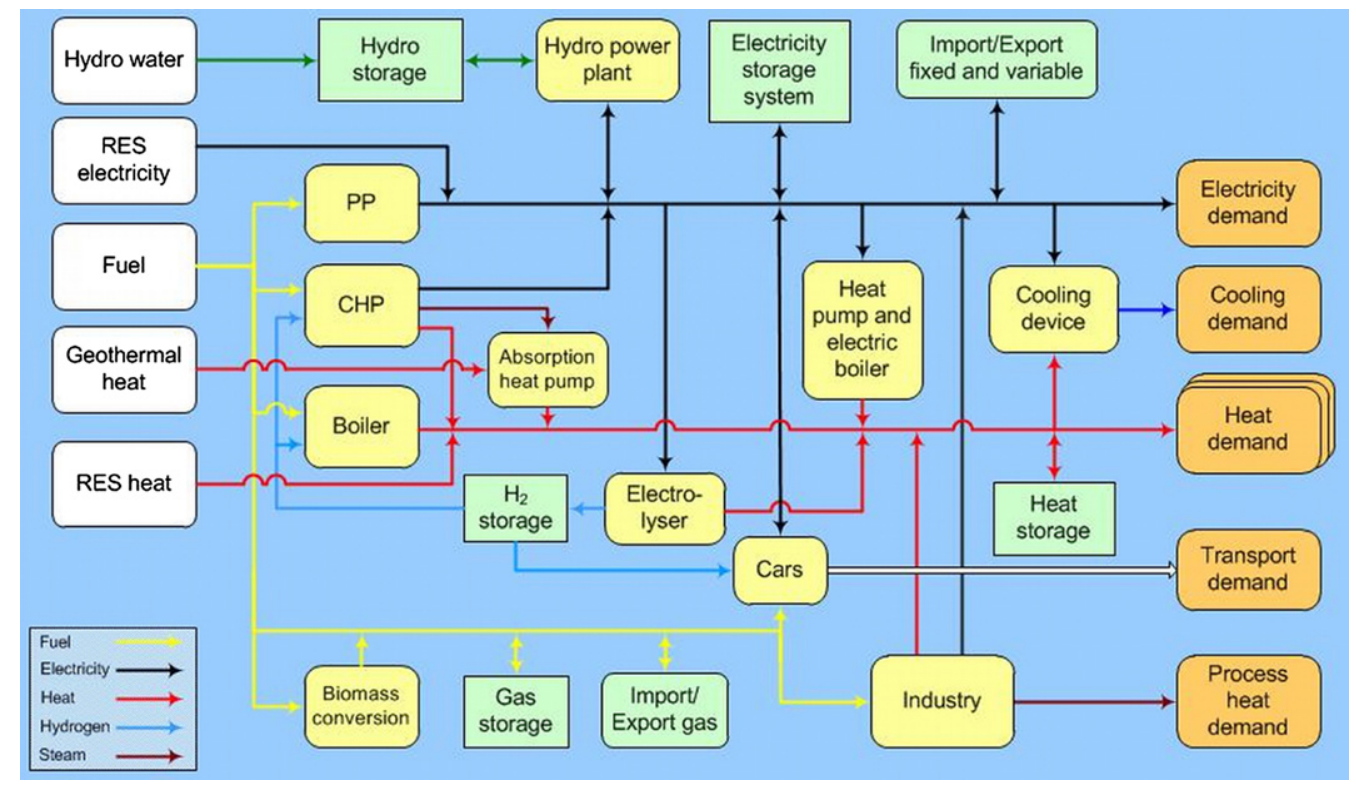

Fig. 1. Schematic diagram of the EnergyPLAN model [33]. 
regulation strategy - balancing both heat and electricity demands have been used.

\section{Planning of the macedonian energy system}

\subsection{Reference scenario for the year 2030}

The reference scenario for the year 2030 is created by expanding the 2008 scenario from Ref. [34] and the 2020 scenario from Ref. [35] with the assumed rise of demand in agricultural, forest, commercial, industrial, transport and residential sector according to the baseline scenario from the Macedonian Energy Strategy [24]. According to authors Ref. [24], Macedonian electricity demand is expected to rise from $7.68 \mathrm{TWh}$ in 2008 to $12.37 \mathrm{TWh}$ in 2030 , equal to an annual rise of $2.11 \%$. Furthermore, the final energy demand in Macedonia is expected to rise from 109.61 PJ in 2020 to $140.09 \mathrm{PJ}$ in 2030 [24] with the highest increase in transport sector.

Total installed capacity of thermal power plants in reference scenario is $1375 \mathrm{MW}$ [24] with a technical minimum of $510 \mathrm{MW}$ [35]. Installed capacity of large hydro power plants is $800 \mathrm{MW}$ while the installed capacity of pumped hydro storage power plant is 347/ $332 \mathrm{MW}$ [24]. Also, the reference system includes $300 \mathrm{MW}$ installed wind power capacity, $100 \mathrm{MW}$ photo voltaic and $160 \mathrm{MW}$ of running river capacity [35]. Distribution curve with hourly resolution for wind was created using hourly wind speed provided by METEONORM program [36]. Hourly production data for hydro power plants have been obtained from the Electricity Transmission System Operator of Macedonia [37] for the year 2009 while hourly load data for the Macedonian power system have been provided by ENTSO-E for the year 2008 (Fig. 2 [38]). The load curve for the hourly district heating demand has been calculated by using degree-day and temperature obtained from METEONORM program [36].

Investment costs for new energy units have been obtained from Refs. $[14,15,39]$ and from the Strategic Energy Technology Information System (SETIS) web calculator [40]. The fuel prices in the year 2008, 2020 and 2030 were obtained from [9]. The fuel prices in the year 2050 were calculated using the price ratio between crude oil and different types of fuels. In order to identify the future price of fuels in the year 2050 , assumption of $200 \$ /$ bbl for crude oil price was used [7]. Also, the following price ratios were used to identify different prices of fuels in the year 2050 [35] and [41]: ratio of crude oil to coal was 0.24 , crude oil to fuel oil 0.71 , crude oil to diesel 1 , crude oil to petrol 1.09 , crude oil to natural gas 0.64 , crude oil to liquefied petroleum gas (LPG) 0.977 , and crude oil to biomass was 0.2 . The $\mathrm{CO} 2$ content in the fuels used in the calculation were obtained from [35]. The fuel prices and $\mathrm{CO} 2$ content in the fuels used in the calculation are presented in Table 1.
Table 1

Fuel prices and $\mathrm{CO}_{2}$ content in the fuels used in the calculation.

\begin{tabular}{cllllllll}
\hline & $\begin{array}{l}\text { Crude } \\
\text { oil }\end{array}$ & Coal & $\begin{array}{l}\text { Fuel } \\
\text { oil }\end{array}$ & Diesel & Petrol & N. Gas & LPG & Biomass \\
\hline $\begin{array}{c}2008 \text { fuel } \\
\text { prices } \\
{[€ / G J]}\end{array}$ & - & 2.1 & 10.76 & 14.8 & 16.2 & 4.87 & 11.27 & 2.66 \\
$\begin{array}{c}2020 \text { fuel } \\
\text { prices } \\
{[€ / G J]}\end{array}$ & 17.44 & 3.76 & 12.93 & 17.78 & 19.50 & 10.18 & 13.54 & 3.26 \\
$\begin{array}{c}2030 \text { fuel } \\
\text { prices } \\
{[€ / G J]}\end{array}$ & 20.93 & 4.53 & 17.78 & 22.02 & 25.04 & 12.25 & 17.6 & 3.80 \\
$\begin{array}{c}2050 \text { fuel } \\
\text { prices } \\
{[€ / G J]}\end{array}$ & 34.88 & 8.29 & 30.71 & 34.88 & 38.02 & 22.43 & 26.86 & 7.06 \\
$\begin{array}{c}\text { CO } 2 \text { content } \\
\text { in fuels } \\
{[\mathrm{kg} / \mathrm{G}]}\end{array}$ & & 101.2 & 74 & 74 & 74 & 56.7 & 66.7 & - \\
\hline
\end{tabular}

\subsection{Input data for the renewable energy system in Macedonia-} closed system calculations

The renewable energy scenarios for the years 2030 and 2050 are based on extensive energy savings through introduction of new technologies and phasing out old ones, and on high penetration of RES in combination with storage technologies. These changes are introduced in the reference scenario for the year 2030.

In order to quantify energy savings, fuel mixes and long term energy demand projections in industry, transport, residential, public services and commercial sector, energy demand models developed for Croatia have been used [42-45]. The model required extensive input data such as population information and future fluctuation, total number of vehicles, type of vehicles and consumption, available floor area, available envelope surface, specific climatic regions, hourly distribution of temperature, heating and cooling degree days, etc. all of which can be imported into the model. In the case of Macedonia, all specific data were obtained from the Macedonian Bureau of Statistic [46], the Macedonian Energy Strategy [24] and from the International Energy Agency [47]. Taking into account the specificness of the analysed country, energy savings and fuel mixes for different sectors were estimated, and following data have been proposed for 50\% renewable energy system in the year 2030:

Individual:

- Reduction of electricity demand in buildings (residential, commercial and service) by $25 \%$

- Reduction of heat demand in buildings by $35 \%$

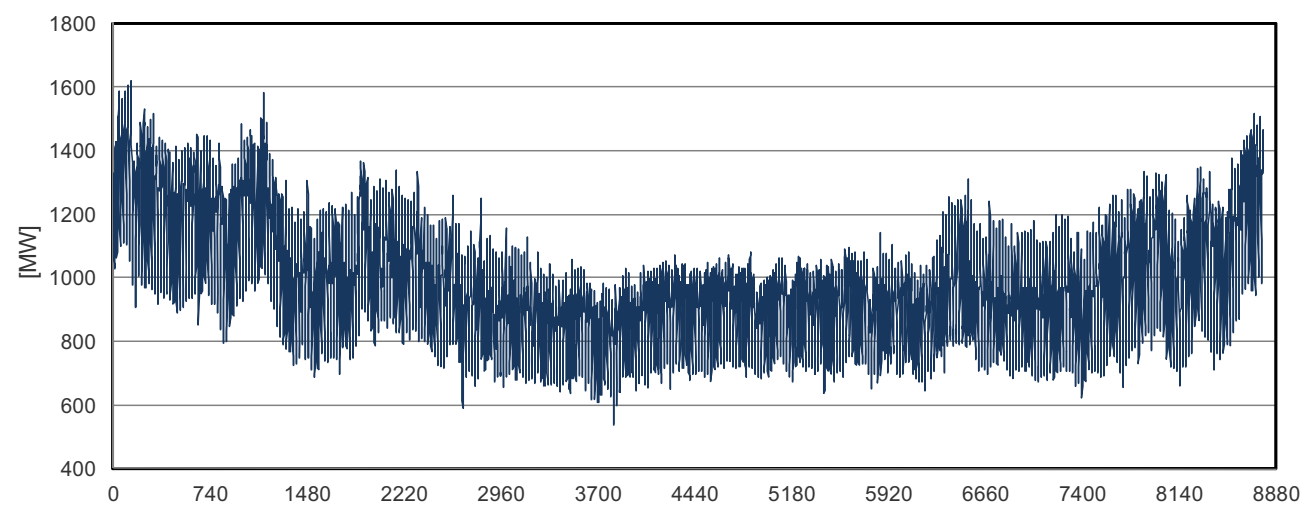

Fig. 2. Hourly power load for Macedonia in 2008 [38]. 


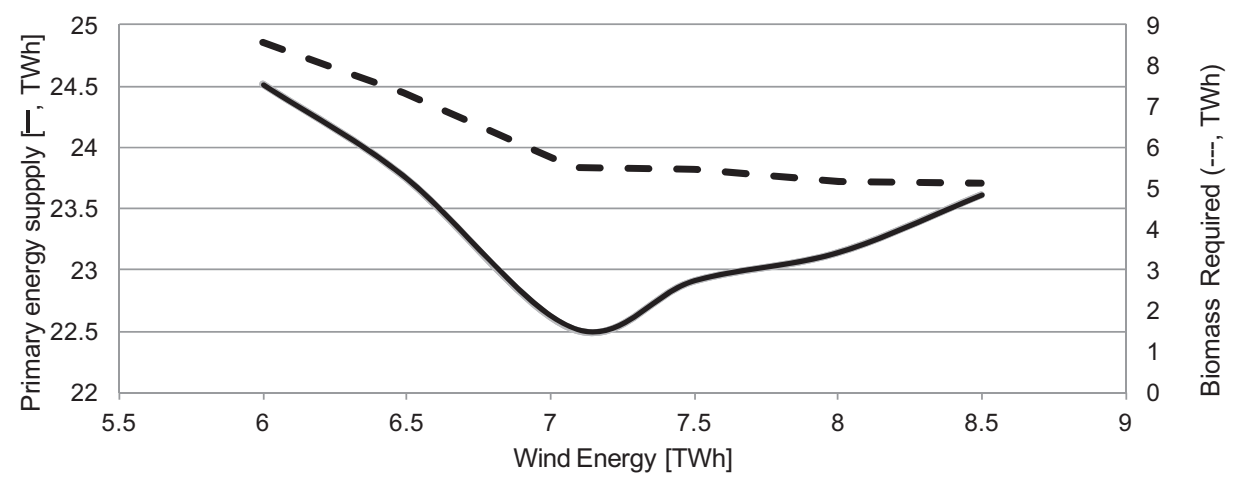

Fig. 3. Primary energy supply and biomass required for different wind production in the $100 \%$ renewable energy system of Macedonia.

- Replacement of coal boilers in buildings with heat pumps

- Replacement of 35\% of oil boilers in buildings with heat pumps

- Replacement of $15 \%$ of natural gas and biomass boilers with heat pumps

- Replacement of $50 \%$ of electricity heating in buildings with heat pumps

- Supply $20 \%$ of heat demand in buildings by solar thermal Industry:

- Reduction of electricity demand in industry by $35 \%$

- Reduction of fuel demand in industry by $20 \%$

- Replacement of $15 \%$ of oil, coal and natural gas consumption in industry with electricity

- Replacement of $50 \%$ of coal and natural gas consumption in industry with biomass

- Supply $20 \%$ of heat demand in industry by solar thermal

Transport:

- Reduction of fuel consumption in transport sector by $25 \%$ with renewal of the fleet

- Replacement of $25 \%$ of fuels (petrol and diesel) for transportation with biofuels and $30 \%$ with electric vehicles

Generation capacity:

- Decommission of 3 coal power plants (Bitola 1, Bitola 2 and Oslomej)

- Increase in solar power from $100 \mathrm{MW}$ to $1100 \mathrm{MW}$

- Increase in wind power from $300 \mathrm{MW}$ to $1500 \mathrm{MW}$

- Increase in PHS from $350 \mathrm{MW}$ to $700 \mathrm{MW}$

- Replace coal and oil DH boilers with natural gas

- Technical minimum of the PP is set at $125 \mathrm{MW}$
In the case of the $100 \%$ renewable energy system in the year 2050, following data are proposed:

Individual:

- Reduction of heat demand in buildings by $10 \%$

- Replacement of remaining electric heating in buildings with heat pumps

- Replacement of remaining oil and natural gas boilers in buildings with heat pumps

- Supply $20 \%$ of heat demand in buildings with solar thermal Industry:

- Reduction of electricity demand in industry by $15 \%$

- Reduction of fuel demand in industry by $20 \%$

- Replacement of $15 \%$ of fuel consumption in industry with solar thermal

- Replacement of $5 \%$ of fuel consumption in industry with electricity

- Replacement of the remaining coal, natural gas and oil fuel demands in industry with biomass

Transport

- Replacement of the remaining conventional vehicles on fossil fuels with electric vehicles

Generation capacity:

- Increase in solar power from $1100 \mathrm{MW}$ to $1600 \mathrm{MW}$

- Introduction of $50 \mathrm{MW}$ of geothermal power plants

- Introduction of $50 \mathrm{MW}$ of large heat pumps in district heating area

- Increase in pumped hydro storage from $700 \mathrm{MW}$ to $1800 /$ $1500 \mathrm{MW}$

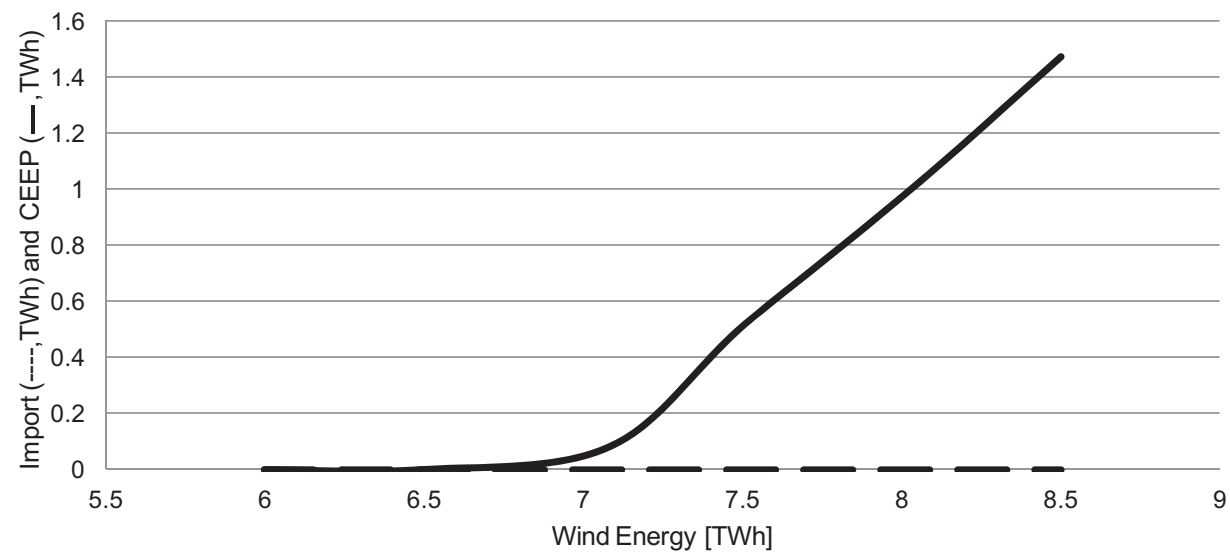

Fig. 4. Critical excess electricity production for different wind production in the $100 \%$ renewable energy system of Macedonia. 


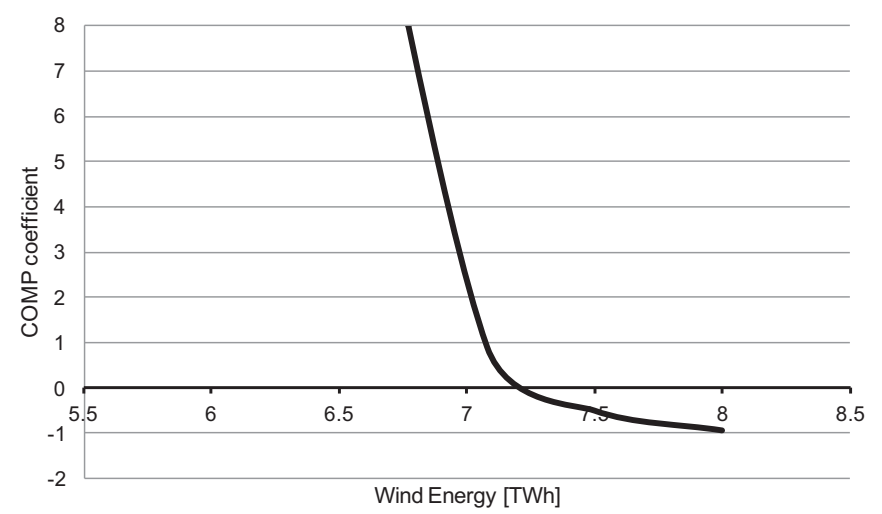

Fig. 5. COMP coefficient for different wind production.

- Decommission of coal and gas fired power plants

- Biomass resources and wind power are used as residual resources and they have to be calculated

\section{Results and discussion}

The analyses in the EnergyPLAN model are conducted for the closed energy system, which means that the total electricity and heat demand is covered by own production and in some cases critical excess of electricity (CEEP) can occur. CEEP is the amount of excess electricity produced that could not be used in the energy system. This excess is the result of the mismatch between supply and demand, and the inability of the energy system to absorb the extra electricity. Furthermore, it is assumed that at least $30 \%$ of the power at any hour must come from power units capable of supplying ancillary services needed for grid stability (central power plant, CHP and hydro power plant) $[5,48]$.

\subsection{Wind power and biomass in the renewable scenario for Macedonia}

After entering all assumptions in the model for $100 \%$ renewable energy system of Macedonia, the optimum solution for wind power and biomass resources mix has been investigated. The optimum solution is the one which maximises the usage of wind power, minimises export and import of electricity and at the same time reduces energy consumption and hence lowers the primary energy supply (PES). Analyses for CEEP, PES, biomass demand and import of electricity were conducted by varying wind production from $5.5 \mathrm{TWh}$ to $8.5 \mathrm{TWh}$ in steps of $0.5 \mathrm{TWh}$ and the results are presented in Figs. 3 and 4.

Fig. 3 shows that the increase of wind production in the beginning phase lead to decrease of PES and after reaching the minimum on $22.5 \mathrm{TWh}$ (with wind production around $7 \mathrm{TWh}$ ), PES increases with adding wind power. The PES curve has this shape because in the beginning, adding wind power leads to reduction in usage of fossil fuels and biomass, but after reaching the minimum, adding wind power leads to an increase in PES and this is because the energy system can not accept any more wind power and CEEP has occurred. Also, Fig. 3 shows that adding wind power leads to a decrease in biomass required for the energy purpose. The increase in wind production from $6.5 \mathrm{TWh}$ to $7 \mathrm{TWh}$ lead to decrease in biomass consumption for $1.83 \mathrm{TW}$ h and this decrease in biomass consumption is caused by the reduction in CHP production. Furthermore, additional increase of wind power lead to very small decrease in biomass consumption and this is because the heat pumps are already operating at maximum capacity and the production of CHP plant is reduced at the maximum.

The results in Fig. 4 show that the critical excess of electricity will not occur if the wind production is below $7 \mathrm{TW} h$, but results in Fig. 3 show that this will lead to an increase in biomass consumption because the biomass will be needed to supplement the production of electricity from wind power.

In order to determine the optimum solution for wind power and biomass residuals, compromise coefficient (COMP) was used. This coefficient is used to illustrate the effect of adding wind power on CEEP and PES and represents a ratio between the decreased PES $(\triangle \mathrm{PES})$ and increased CEEP $(\triangle \mathrm{CEEP}), \mathrm{COMP}=\Delta \mathrm{PES} / \Delta \mathrm{CEEP}[27,41]$. The optimum level of adding wind power is found when COMP coefficient is around 1. The COMP coefficient for the 100\% renewable energy system of Macedonia is presented in Fig. 5.

As a result of the COMP coefficient analysis, wind production of $7 \mathrm{TW} h$ and biomass requirements of $5.5 \mathrm{TWh}$ were selected as the optimal solutions and these values will be used for the

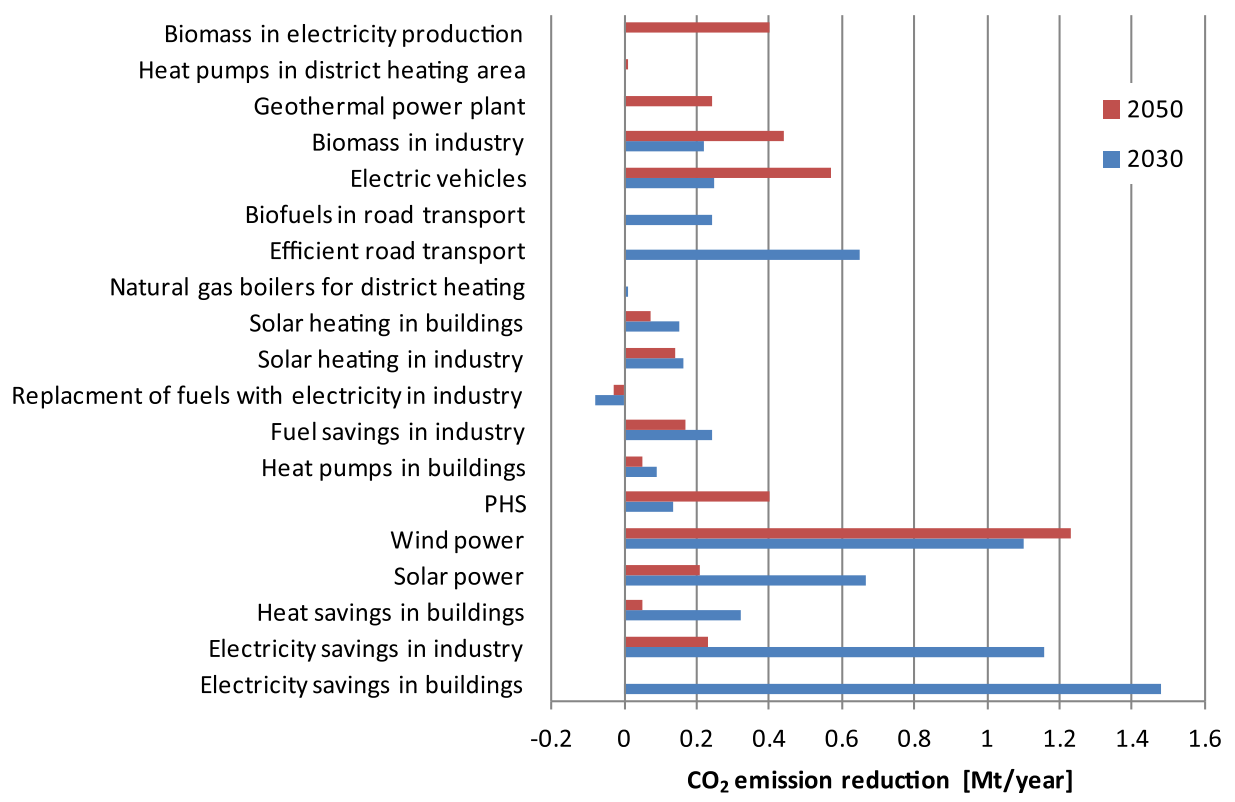

Fig. 6. $\mathrm{CO}_{2}$ reduction achieved through individual measures estimated for the future renewable energy systems of Macedonia in the years 2030 and 2050 . 


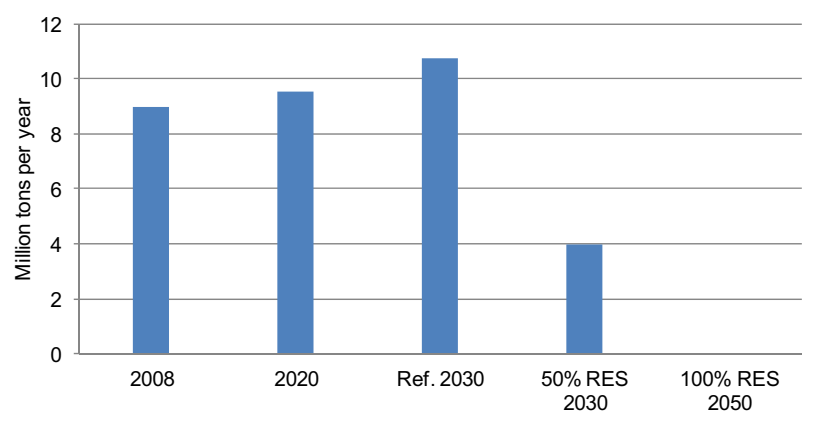

Fig. 7. $\mathrm{CO}_{2}$ emissions from different scenarios in Macedonia.

analysis of the $100 \%$ renewable energy system of Macedonia in the year 2050.

\subsection{Environmental evaluation of individual measures and energy scenarios}

The $\mathrm{CO}_{2}$ emission reductions achieved through individual measures were calculated for the years 2030 and 2050 and the results of this analysis are presented in Fig. 6. Wind power and electric savings in buildings and industry have the highest impact on the $\mathrm{CO}_{2}$ reduction. As it can be seen in Fig. 6 most measures have positive impact on the $\mathrm{CO}_{2}$ reduction, while only replacement of fossil fuels in industry with electricity has a negative impact on the $\mathrm{CO}_{2}$ reduction, but this measure has a very positive impact on CEEP. Furthermore, measures like heat pumps in buildings, heat pumps in district heating and electric vehicles are introduced because they have a very positive impact on decreasing CEEP.

The $\mathrm{CO}_{2}$ content in the fuels from Table 1 has been used in order to calculate $\mathrm{CO}_{2}$ emissions associated with each of the scenarios (Fig. 7). Results show that the decrease of PES in the 50\% renewable energy system scenario will lead to a significant decrease of $\mathrm{CO}_{2}$ emissions. The reference scenario in the year 2030 has the highest $\mathrm{CO}_{2}$ emissions followed by the reference scenarios in the year 2020 [35] and 2008 [34]. Compared to the reference scenario in the year 2030 , the decrease of $\mathrm{CO}_{2}$ emissions will be $63.2 \%$, while the decrease of $\mathrm{CO}_{2}$ emissions compared to the reference scenario in the year 2008 will be $60 \%$. In the $100 \%$ renewable energy system, $\mathrm{CO}_{2}$ emissions are equal to zero.

\subsection{Economic evaluation of energy scenarios}

This section presents the results of analysis for annual operating costs in reference scenario and two renewable scenarios in the years 2030 and 2050. For this calculation, fuel prices from Table 1

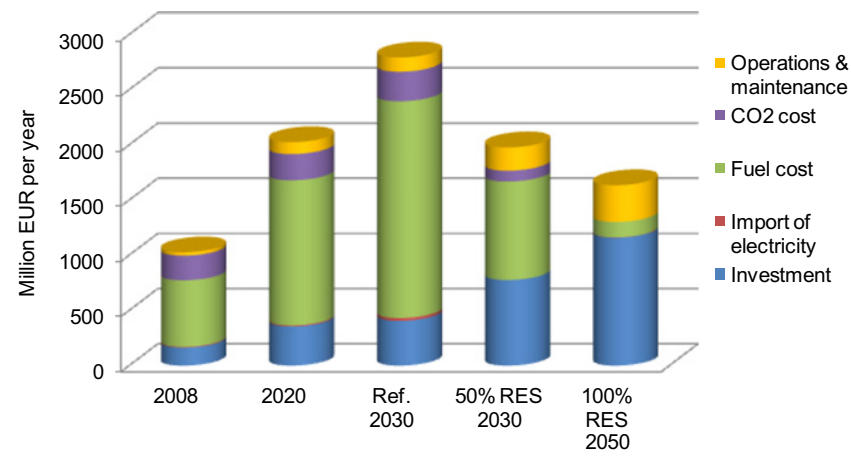

Fig. 8. Annual operating costs of the various scenarios

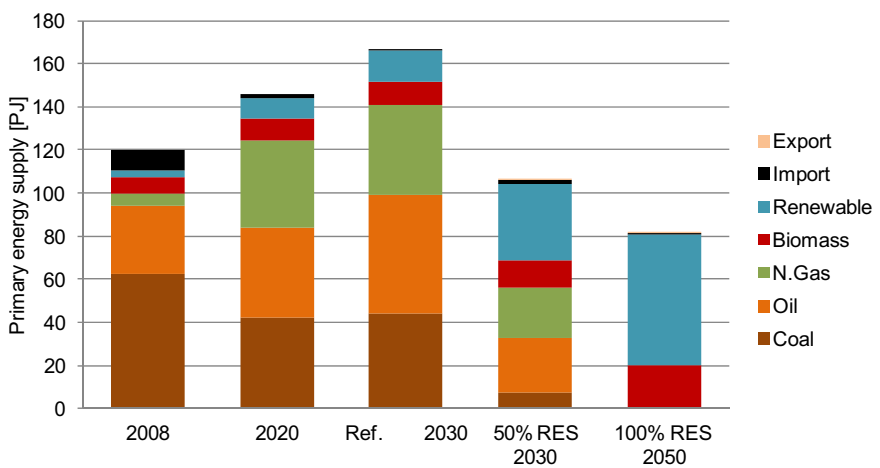

Fig. 9. Primary energy supply for the renewable energy scenarios in Macedonia.

and $\mathrm{CO}_{2}$ price of $25 € / \mathrm{t}$ [35] have been used. Operating, maintaining and investment costs of the existing thermal (condensing and CHP) and hydro power plants, as well as for the planned power plants, were obtained from Refs. [24,35]. The investment and operating costs for renewables and heat pumps were obtained from the report completed by the Danish Energy Authority [39]. The result of the economic analysis for five different scenarios is shown in Fig. 8.

Reference scenario in the year 2030 is the most expensive scenario due to high consumption of fossil fuels and because of $\mathrm{CO}_{2}$ emissions. In the case of the $50 \%$ renewable energy scenario, fuel costs are decreased compared to the reference scenario in 2030 due to investments in new technologies and energy savings. The 100\% renewable energy system has the lowest fuel cost compared to reference scenario, but in this scenario annual investment costs are the highest. Total annual investment cost for the 50\% renewable energy system is 776 million Euros while the annual investment costs for the $100 \%$ renewable energy system is 1161 million Euros.

\subsection{Fuel consumption of the Macedonian energy systems}

This section presents the results of analysis for PES conducted for the renewable energy systems in the years 2030 and 2050. By using assumption from the Section 3.2 PES for the years 2030 and 2050 were calculated. The result of this analysis is presented in Fig. 9. Total PES in the reference scenario for the year 2030 is $166 \mathrm{PJ}$, in the scenario for the 50\% renewable energy system it is $107 \mathrm{PJ}$ and in the $100 \%$ renewable energy system total PES is $81 \mathrm{PJ}$.

In the $100 \%$ renewable energy system biomass has the highest share in the total PES. In this scenario biomass is participating with

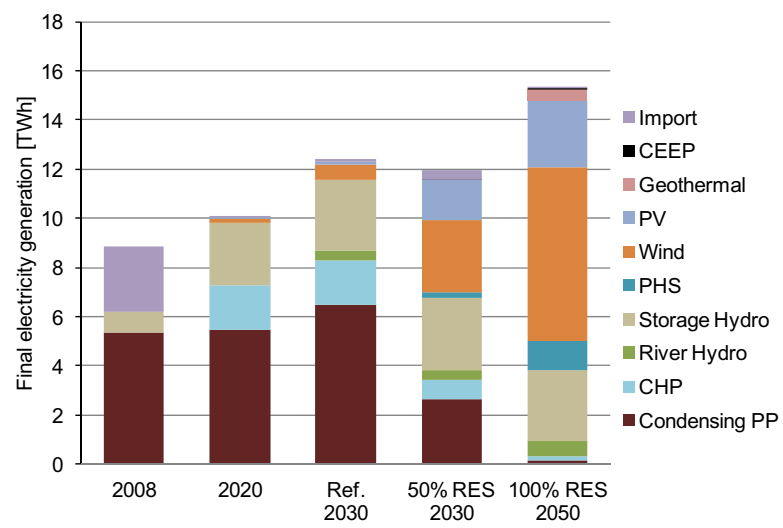

Fig. 10. Electricity generation by technologies for different scenarios. 
$19.8 \mathrm{PJ}$, while in the $50 \%$ renewable energy scenario biomass is participating with 12.6 PJ. The biomass consumption in the 50\% RES scenario has been increased by $14 \%$ and in the $100 \%$ RES scenario by $50 \%$ compared to the reference scenario in the year 2030 .

Electricity generation by different technologies in five scenarios is presented in Fig. 10. The results indicate that the generation capacities of wind, PV, large hydro and PHS, are significantly increased in order to replace decommission of traditional technology based on fossil fuels.

Production of electricity from wind in the 50\% RES scenario is 2.93 TW $\mathrm{h}$, from PV 1.61 TW $\mathrm{h}$ and from large hydro $2.9 \mathrm{TW} \mathrm{h}$. In the case of the $100 \%$ RES scenario production of electricity from wind is 7.08 TW h, from PV 2.69 TW h and from large hydro 2.9 TW h.

\section{Conclusion}

In this paper the $100 \%$ renewable energy system of Macedonia in the year 2050 is designed. The results of analyses show that the $100 \%$ renewable energy system in Macedonia is possible however, to achieve this goal high share of biomass, wind power and solar power as well as different storage technologies are needed. Also, all analyses have been conducted with the existing technologies and with the high emphasis on the new storage technologies such as electric vehicles and heat pumps in order to increase the penetration of the intermittent RES and to decrease critical excess of electricity. In the case of the 100\% renewable energy system biomass is participating in the PES with $19.8 \mathrm{PJ}$, while in the case of the $50 \%$ renewable energy system biomass is participating with 12.6 PJ. However, 19.8 PJ of biomass may be too high for Macedonia and because of that additional energy efficiency measures are needed in order to decrease the biomass needs for designing the $100 \%$ renewable energy system. Furthermore, energy savings applied to a design of renewable energy system, as well as new efficient technologies used for the production of heat and electricity, have led to a decrease of total PES for $35 \%$ in the case of the $50 \%$ renewable energy system and for $51 \%$ in the case of the $100 \%$ renewable energy system compared to the reference energy system in the year 2030 . At the moment the $50 \%$ renewable energy system seems much more likely than the $100 \%$ renewable energy system, and with new energy efficiency measures which will lead to a decrease of consumption and installation of new generation capacities this goal can be easily achieved.

\section{References}

[1] Rio PD. Analysing future trends of renewable electricity in the EU in a lowcarbon context. Renewable and Sustainable Energy Reviews 2011;15(5): 2520-33.

[2] Krajačić G, Duić N, Carvalho MG. H2RES, Energy planning tool for island energy system - the case of the Island of Mljet. International Journal of Hydrogen Energy 2009;34(16):7015-26.

[3] Ćosić B, Stanić Z, Duić N. Geographic distribution of economic potential of agricultural and forest biomass residual for energy use: case study Croatia. Energy 2011;36(4):2017-28.

[4] Connolly D, Lund H, Mathiesen BV, Pican E, Leahy M. The technical and economic implications of integrating fluctuating renewable energy using energy storage. Renewable Energy 2012;43:47-60.

[5] Krajačić G, Duić N, Tsikalakis A, Zoulias M, Caralis G, Panteri E, et al. Feed-in tariffs for promotion of energy storage technologies. Energy Policy 2011; 39(3):1410-25.

[6] Kaldellis JK, Zafirakis D, Kavadias K. Techno-economic comparison of energy storage systems for island autonomous electrical networks. Renewable and Sustainable Energy Reviews 2009;13(2):378-92.

[7] RE-thinking 2050, A 100\% renewable energy vision for the European union. European Renewable Energy Council [internet]. Available at: http://www. rethinking2050.eu/index.php?id=4; April 2010 [accessed 29.10.11].

[8] Lund H, Mathiesen B. Energy system analysis of $100 \%$ renewable energy systems - the case of Denmark in years 2030 and 2050. Energy 2009;34(5): 524-31.

[9] Krajačić G, Duić N, Zmijarević Z, Mathiesen BV, Anić-Vučinić A, Carvalho MG. Planning for a $100 \%$ independent energy system based on smart energy storage for integration of renewables and $\mathrm{CO}_{2}$ emissions reduction. Applied Thermal Engineering 2011;31(13):2073-83.

[10] Krajačić G, Duić N, Carvalho MG. How to achieve a 100\% RES electricity supply for Portugal. Applied Energy 2011;88(2):466-72.

[11] Connolly D, Lund H, Mathiesen BV, Leahy M. The first step towards a $100 \%$ renewable energy-system for Ireland. Applied Energy 2011;88(2):502-7.

[12] Mason IG, Page SC, Williamson AG. A 100\% renewable electricity generation systems for New Zealand utilising hydro, wind, geothermal and biomass resources. Energy Policy 2010;38(8):3973-84.

[13] Elliston B, Diesendorf M, MacGill I. Simulations of scenarios with $100 \%$ renewable electricity in the Australian national electricity market. Energy Policy 2012;45:606-13.

[14] Østergaard PA, Mathiesen BV, Möller B, Lund H. A renewable energy scenario for Aalborg Municipality based on low-temperature geothermal heat, wind power and biomass. Energy 2010;35(12):4892-901.

[15] Østergaard PA, Lund H. A renewable energy system in Frederikshavn using low-temperature geothermal energy for district heating. Applied Energy 2011;88(2):479-87.

[16] Segurado R, Krajačić G, Duić N, Alves L. Increasing the penetration of renewable energy resources in S. Vicente, Cape Verde. Applied Energy 2011; 88(2):466-72.

[17] Duić N, Carvalho MG. Increasing renewable energy sources in island energy supply: case study Porto Santo. Renewable and Sustainable Energy Reviews 2004;8(4):383-99.

[18] Blarke $M$, Lund $H$. The effectiveness of storage and relocation options in renewable energy systems. Renewable Energy 2008;33(7):1499-507.

[19] EUROSTAT. European statistic [internet]. European Commission. Available at: <http://epp.eurostat.ec.europa.eu/portal/page/portal/energy/data/database > [accessed 21.05.12].

[20] Taseska V, Markovska N, Causevski A, Bosevski T, Pop-Jordanov J. Greenhouse gases (GHG) emissions reduction in a power system predominantly based on lignite. Energy 2011;36(4):2266-70.

[21] IEA. Energy in the Western Balkans - the path to reform and reconstruction. Paris, France: IEA Publications, ISBN 978-92-64-04218-6; 2008.

[22] Markovska N, Taseska V, Pop-Jordanov JSWOT. Analyses of the nationa energy sector for sustainable energy development. Energy 2009;34(6):752-6.

[23] Markovska N, Todorovski M, Bosevski T, Pop-Jordanov J. Cost and environmental effectiveness of climate change mitigation measures. Sustainable energy production and consumption. Springer Science; 2008. 67-73.

[24] Strategy for energy development in the republic of Macedonia until 2030 Skopje, Macedonia: Macedonian Ministry of Economy [internet]. Available at: <http://www.ea.gov.mk/projects/unece/docs/legislation/Macedonian_Energy_ Strategy_until_2030_adopted.pdf $>$; 2010 [accessed 21.05.12].

[25] EnergyPLAN: Advanced energy system analysis computer model [internet] Aalborg University, Denmark. Available at: <http://energy.plan.aau.dk $>$ [accessed 21.05.2012].

[26] Lund H. Large-scale integration of wind power into different energy systems. Energy 2005;30(13):2402-12.

[27] Liu W, Lund H, Mathiesen BV. Large-scale integration of wind power into existing Chinese energy systems. Energy 2011;36(8):4753-60.

[28] Lund H. Large-scale integration of optimal combinations of PV, wind and wave power into the electricity supply. Renewable Energy 2006;31(4):503-15.

[29] Lund H, Andersen AN. Optimal designs of small CHP plants in a market with fluctuating electricity prices. Energy Conversion and Management 2005;46(6):893-904

[30] Lund $\mathrm{H}$, Munster E. Integrated transportation and energy sector $\mathrm{CO}_{2}$ emission control strategies. Transport Policy 2006;13(5):426-33.

[31] Mathiesen BV, Lund H, Norgaard P. Integrated transport and renewable energy systems. Utilities Policy 2008;16(2):107-16.

[32] Nielsen S, Sorknæs P, Østergaard PA. Electricity market auction settings in a future Danish electricity system with a high penetration of renewable energy sources - a comparison of marginal pricing and pay-as-bid. Energy 2011;36(7):4434-44.

[33] Lund H. EnergyPLAN - advanced energy system analysis computer model users manual documentation version 9.0. Aalborg, Denmark: Aalborg University; 2011.

[34] Ćosić B, Markovska N, Taseska V, Krajačić G, Duić N. The potential of GHC emissions reduction in Macedonia by renewable electricity. Chemical Engineering Transaction 2011;25:57-62.

[35] Ćosić B, Markovska N, Krajačić G, Taseska V, Duić N. Environmental and economic aspects of higher RES penetration into Macedonian power system. Applied Thermal Engineering 2012;43:158-62.

[36] METEONORM. Global meteorological database for engineers, planners and education [internet]. Available at: <http://www.meteonorm.com/pages/en/ meteonorm.php $>$ [accessed 21.05.12].

[37] MEPSO. Electricity transmission system operator of Macedonia [internet]. Available at: <http://www.mepso.com.mk/en-us/Listanjelzveshtai.aspx? categoryID $=138>$ [accessed 21.05.12]

[38] ENTSO-E. European network of transmission system operators for electricity [internet]. Available at: <https://www.entsoe.eu/db-query/country-packages/ production-consumption-exchange-package/> [accessed 21.05.12]

[39] Technology data for energy plants [internet]. Danish Energy Agency. Available at: http://www.ens.dk/Documents/Netboghandel-publikationer/2010/Technology_ data_for_energy_plants.pdf [accessed 21.05.12].

[40] SETIS calculator [internet]. JRC, European Commission. Available at: < https:// odin.jrc.ec.europa.eu/SETIS/SETIS1.html\#> [accessed 21.05.12] 
[41] Connolly D, Lund H, Mathiesen BV, Leahy M. Modelling the existing Irish energy-system to identify future energy costs and the maximum wind penetration feasible. Energy 2010;35(5):2164-73.

[42] Pukšec T, Mathiesen BV, Duić N. Potentials for energy savings and long term energy demand of Croatian households sector. Applied Energy, 2012, http:/ dx.doi.org/10.1016/j.apenergy.2012.04.023.

[43] Irsag B, Pukšec T, Duić N. Long term energy demand projection and potential for energy savings of Croatian tourist-catering trade sector. In: Proceedings of the 6th Dubrovnik Conference on Sustainable Development of Energy, Water and Environment Systems, 25-29 September 2011, Dubrovnik, Croatia.

[44] Pavković D, Pukšec T, Duić N. Energy demand modelling for the Croatian education sector. In: Proceedings of the 21st International symposium on heating, refrigerating and air conditioning, 07-08 April 2011, Zagreb, Croatia.

[45] Pukšec T, Mathiesen BV, Duić N. Long term energy demand projections for Croatian transport sector. In: Proceedings of the 24th international conference on efficiency, cost, optimisation, simulation and environmental impact of energy systems, 04-07 July 2011, Novi Sad, Serbia.

[46] Macedonian bureau of statistics [Internet]. Available at: <http://www.stat. gov.mk/Default_en.aspx $>$ [accessed 21.05.12].

[47] International Energy Agency (IEA) [Internet]. Available at: <http://www.iea. org/countries/non-membercountries/macedoniatheformeryugoslavrepublicof/> org/countries/non-ment.

[48] Hong L, Lund H, Moller B. The importance of flexible power plant operation for Jiangsu's wind integration. Energy 2012;41(1):499-507. 